\title{
The Effects of Spontaneous Use of Smartphone on the Attention and Emotions of Millennials Students in a Classroom
}

\author{
Cristóbal Fernández Muñoz ${ }^{1}$, Isidoro Arroyo Almaraz ${ }^{2} \&$ Francisco Garrcía García ${ }^{1}$ \\ ${ }^{1}$ Complutense University, Madrid, Spain \\ ${ }^{2}$ Rey Juan Carlos University, Madrid, Spain \\ Correspondence: Cristóbal Fernández Muñoz, School of Communication, Complutense University, Av. \\ Complutense, 3. 28040 Madrid, Spain. E-mail: cristfer@ucm.es
}

Received: June 10, 2019; Accepted: June 18, 2019; Published: June 30, 2019

\begin{abstract}
With the access of the millennials to the contents of the internet through their smartphones, a new educommunicative ecosystem emerges that favors communication through immediacy and interactivity. This research seeks to know the habitual and spontaneous use of millennial smartphone during an on-campus class at the university. Experimental research has been used, using neuroscientific techniques of electrodermia, to measure the attention of subjects and their emotions at the group level, as well as a complementary quantitative questionnaire. The experiment was carried out with 44 people distributed in the two groups with 22 subjects in each one (experimental group and control group), with ages between 20 and 21 years of age of both sexes (in a similar proportion). $45 \%$ said they use the smartphone in class to chat, $29 \%$ to enter social networks and $5 \%$ indicated the use of the smartphone to take photos. $21 \%$ said they never use the smartphone in class. Regarding the neuroscientific experiment there was an increase in attention in the session in which the use of smartphone was prohibited. The students declare that they have smartphone usage patterns in the classroom similar to those they have outside the classroom. There were no significant differences in the duration and average intensity of attention and emotion between the experimental group and the control group.
\end{abstract}

Keywords: smartphone, millennials, neuroscience, education, communication

\section{Introduction}

The digital communication tools opened a new way to access internet content through smartphones in the last decade. With mobility in access to the network, immediacy and interactivity increases, what multiplies the effectiveness of digital communication and this favors the emergence of a new communicative ecosystem that is not limited exclusively to the digital world, even less in the case of millennials since they establish connections between the online and offline world, as shown by some authors (Olsson \& Dahlgren, 2010).

However, in this new ecosystem the youngest among the millennials, the so-called $\mathrm{Z}$ Generation, tend to reduce communication to those media that facilitate immediacy, as authors such as Alonso and Fraga (2016) have pointed out: "Results warn about the interests of young people towards social networks and their need of immediacy (with services such as WhatsApp), discarding email as a form of communication. Young women spend more time using social networks ( $50 \%$ between 1 and 3 hours a day). "

The so-called millennial generations, those born after 1980, are divided into millennials and $\mathrm{Z}$ generation, also known as iGen, centennials, K generation or Founders (Dorsey, 2016). According to Estefanía (2017) the youngest millennials, centennials or generation $\mathrm{K}$, take the initial $\mathrm{K}$ from the name of "Katniss Everdeen, the tenacious heroine of the movie The Hunger Games played by Jennifer Lawrence. Like her, these young people, especially girls, between 13 and 20 years old, feel that they live in a world in permanent conflict. A violent, dystopian and unjust society to which they must react".

Estefanía (2017), taking data from Bank of America Merrill Lynch, sets the age of millennials between the ages of nineteen and thirty-five; while determines that centennials are composed by newborns until they reach the age of eighteen. Between them, there would be around 4,400 million people around the world today. If we take into account that the world population is approximately 7,000 million, they represent almost $63 \%$ of the world population. So it is estimated that by 2020 , more than 60 percent of the world population will be less than thirtyfive years old. 


\subsection{Millennials, Students Dependent on the Smartphone}

All of them are digital natives (Prensky, 2001) and communicate through all the possible forms that digital communication is taking (Olabarri \& Monge, 2011). According to the data taken from the latest reports on behavioural profiles as users and consumers in the digital world, they manage their communication according to very specific patterns. This generation predominantly uses the Smartphone in a globalized manner, as evidenced by studies in many countries. In Spain, the data of the 21 st Study "Navigators in the network" made by AIMC (Association for the investigation of Media Communication) in 2019 and with a final useful sample of 20,482 questionnaires, shows that young users dedicate more and more time of connection to Internet through a smartphone.

$90 \%$ of the respondents connected to the internet through the smartphone well above those who connect with: laptop $(69 \%)$, desktop (56\%) or with a tablet (48\%). In addition to the preference of the smartphone over other device, more than half of the subjects say they are almost always connected. $83 \%$ of these young people leave their smartphone on the bedside table while they sleep. Throughout the day they consult it an average of 45 times.

Young people find it difficult to live without internet. Half of them have had a smartphone before entering school, use social networks on a daily basis and communicate with instant messages illustrated with emoticons to which they spend more than an hour a day on average, while a fifth part of them spend over four hours. And they do not despise the use of electronic mail.

It follows that the smartphone is a key element to reach these generations, since this group, according to the Study I Gen Gez Z Tech Disruption Research (2016), spends more time browsing their devices than previous generations. $18 \%$ of I Gen (generation K) say they receive the first smartphone at 13 years old. Recall that the previous generation, millenialls, received it at 18 years. In Europe and particularly in Spain they get it from the Secondary Education. According to Dorsey (2016) "The age at which you get your first phone is more important than the age at which you get your driver's license". Because this generation "listens to their friends and the smartphone".

Regarding the moments of consumption in smartphone devices, according to Ureña (2017), citing the study Connecting generations, Kantar Millward Brown, are characterized by being connected to the internet on evenings, since the youngest are still students with a more conventional schedule. They show more interest in influencers (youtubers, bloggers, instagramers) than previous generations. And its average concentration capacity has fallen from 12 seconds in 2000 to 8 seconds in 2016. So the I Gen or generation K sharpens its interest in immediacy.

We are facing a new hyperconnected generation, digital natives, multi-screen and addicted to apps and social networks, but with marked differences from the previous generation, because, according to the National Study on Technology and the Generation after Millennials (2016), they receive their first smartphone before. Prefer social networks Instagram, Vine or even Twitter before than Facebook to which $44 \%$ consider an intergenerational network that can be used by both their parents and themselves. And they feel more comfortable with smartphone apps.

\subsection{The Smartphone in the Classroom}

If, as we have indicated, the smartphone is inside the classrooms and is part of the values of the young people who dynamize their interactions by building an ideal digital identity, -like the self-referential ideal Belk (2013) -, it must be considered how to use it in favor of teaching and learning processes (Anohah, E., Oyelere, SS, \& Suhonen, J., 2017; Yaacov J. Katz, Yaacov B. Yablon, 2011; Menchaca, I., Guenaga, M., Romero, S., 2015; Artopoulos, A. and Sansone M., 2016).

In this line, authors such as Pérez-Tornero, professor at the Autonomous University of Barcelona (Spain) or Samy Tayie, professor at the University of Cairo, when they claim the urgency of media and information literacy after checking, through the global experiment led by Susan Moeller (2012, p.14) that young people today, regardless of the context in which they live, present a strong feature of addiction to new media and especially to the smartphone from which they cannot disconnect.

This new digital ecosystem generated by the smartphone runs through a virtual territory that starts with WhatsApp and expands on Facebook, Twitter and YouTube. The smartphone provides advantages in the implementation of collaborative methodologies in the teaching-learning process because it extends the participation of students through the messages written in the different messaging formats through social networks and also facilitates the integration of the individual with his peer group (Kotilainen, 2010).

It becomes an instrument that encourages active learning because it dynamizes the tasks of consultation in the classroom, through internet and dictionaries, facilitates calculations, captures and checks data in its original sources, etc. and it slows down the forgetting curve, as more interaction with the contents produces a greater 
retention of the same in the long term, as they proved with university students Guerrero, Jaume, Juiz \& Lera (2016, p. 1) "results show that student participation increases with the use of mobile devices for theory classes and students are willing to participate in class activities and share their own results". In the same way, Navaridas, Santiago \& Touron (2013, p. 1), collected the evaluations of teachers in the Fresno area (central California) on the influence of smartphones on the learning of their students, and concluded that smartphones could have a great pedagogical potential to improve the quality of learning. Most of these professors coincide in pointing out benefits of their use in class, such as: "the increase in students' interest in the task, the increase in activity during the study, a more collaborative work, as well as the improvement of the creativity and the process of acquiring student information".

However, there are not all benefits between smartphones and traditional classes, as shown by Cavanaugh, Giapponi, \& Golden, (2016, p. 1) "there is mounting evidence in the cognitive neuroscience literature that digital technology is restructuring the way our students read and think, and not necessarily for the better". Since they are a safe source of distraction derived from the culture of permanent contact that encourages students to immediately check all messages received and can become an escape valve that facilitates mental escape from the classroom through from that window to the outside world. And also a source of disruption, by the intrusion of sounds alien to the classroom as Campbell (2007, p. 293) pointed out: "Learning is heavily mediated through the experience of being in the classroom. If that experience is interrupted by a mobile phone distraction, there is more at stake".

It can also be an appropriate instrument to copy in the exams through internet connection tools or bluetooth, without internet connection, as evidenced by research carried out in secondary education (Ureta, Artopoulos, Muñoz, Jorquera, 2011, pp. 320-321) so: "From the point of view of the educational institution these are commonly received as a direct attack on the traditional way in which educational practice has been carried out, due to which the first reaction ( and usually the only one) is to openly repress all these practices. "

There are more and more studies that indicate the interaction of WhatsApp in the classroom (for instance Cetinkaya, 2017), that although it can be used to share educational material, keep updated about the evolution of the classes, solve problems in a collaborative way or improve the communication between students and teachers, also point out challenges such as lack of privacy or misuse of chat groups as well as the voluntary exclusion of students without WhatsApp (Mazana, 2018, Hershkovitz et al., 2019).

For all this we are presented with an educational debate because, while on the one hand there are researches that are in favor of the use of smartphones, on the other hand, the negative aspects that this massive use in the classroom entails are considered.

\section{Method}

\subsection{Objectives and Hypotheses}

The project is based on three objectives. First, to know the habitual patterns of use of the smartphone among millennials in the classroom, in a more generic sense. Secondly, investigate the spontaneous use made by millennials of the smartphone in class, investigating the characteristics of it. In third place, to know the disruptive factor of the smartphone in the classroom, as an element that determines or not the didactic act.

Considering the results of the investigations carried out so far in this field, the following hypotheses are proposed:

h.1. When there is no pedagogical instruction, the use of the smartphone in the classroom by millennials will be the same as they usually do outside of it.

h.2 The majority use that millennials make of the smartphone in class is that of instant communication.

h.3. The spontaneous use of the smartphone in the classroom distracts students in class.

\subsection{Design of Experimental Research}

The work developed had a previous investigation of quantitative type through the questionnaire technique to the subjects participating in the experiment.

Then with an experimental research, using neuroscientific techniques of electrodermia, to measure the attention of the subjects and their emotions at the group level, for being one of the most used methods to measure attention and emotion, since it has a peculiarity, according to Tapia and Martín, (2016, p. 71): "It is measured simultaneously to a group of people through a technology called Sociograph, whose viability has been previously tested by Martínez Herrador et al. (2008, 2012), Aiger, M et al. (2013). "In this way we obtained the use of objective techniques complementary to the use of the questionnaire method, as has already been done in other experimental investigations in the field of education (Molina, Navarro, Lacruz and Ortega, 2017, p. 88). 
And, finally, with a questionnaire to the subjects participating in the experiment with a single semi-open question about the specific use they had made of the smartphone during the experiment.

The experimental design was carried out in classroom with two university groups from the third year of the Audiovisual Communication degree, with the S1 group being a control group with an indication of not using smartphone and the S2 group, an experimental group with spontaneous behavior of the use of the smartphone All of them were taught the same class using a didactic methodology that combined a master class with the support of audiovisual material and taught by the same teacher.

The sample, chosen by the convenience sampling method, consisted of 44 people distributed in the two groups with 22 subjects in each, with ages between 20 and 21 years of age of both sexes (in a similar proportion). The two classes were held on January 28, 2016 in a classroom of the School of Social Communication at the Complutense University of Madrid.

In one of the classes the instruction was given that the use of the smartphone was prohibited, while in the other, they are instructed that they can use it or not at their convenience, without encouraging their use.

With the Sociograph technology, a neuroscientific instrument with its own model, the attention and emotion of each group was measured, both in the control group S1 and in the experimental group S2. Sociograph Neuromarketing S.L. (http://www.sociograph.es/) is the owner of the Sociograph patent, which is able to measure, through the electrical activity of the skin, the alert level and the emotional impacts experienced by a group of people before a stimulus.

This technology, counts among its collaborators with prestigious universities such as: University of Salamanca, University of Barcelona, University of Valladolid, European University Miguel de Cervantes of Valladolid, Carlos III University of Madrid and Complutense University.

\subsection{Research Procedure.}

The procedure of the investigation was carried out in the following way: Each student of the experiment had a sensor of their brain activity, collecting information about their attention and their emotions during it. At the entrance to the classroom a bracelet was placed to each participant, who sent the information of each person to a central processing unit, in charge of the necessary calculations and their warehouse. The measuring instrument analysed the electrodermal activity of two types of basic signals. "In the first place the tonic activity, related to the attention (EDL, or electrodermal level). The unit of measurement used is the sum of the electrodermal resistance in Kilomnios (K $\Omega$ ) of all the participants. The lower the resistance, the higher the level of attention. In second place "phasic activity, related to emotion (EDR, or electrodermal response). In this case, the unit of measure is the arithmetic mean of the electrodermal resistance in Kilomnios $(\mathrm{K} \Omega)$ of all the participants. In this case, "the higher the average, the greater the intensity of emotion" (Tapia and Martín, 2016, p. 73).

It should be noted that the machine simply detects the presence of emotion, but not the type or content of it, thus not discriminating between positive or negative emotions.

For the analysis of the collected data, descriptive statistical techniques suited to the characteristics of the time series obtained were used, making use of models for longitudinal studies.

To know the stated smartphone usage habits, as well as the spontaneous use they had made during the experiment, a self-administered and structured questionnaire was used as a data collection technique. The data collection was carried out by means of a questionnaire written at the end of the experiment to all the students who took part in the research. The questionnaire included 13 closed multi-item questions with different options (multiple options, binary and multiple response choices) and a semi-open question about the specific use they had made of the smartphone during the experiment.

\section{Results}

\subsection{Analysis of the Data of the Habitual Use of the Smartphone among Millennials in Class.}

Regarding the results of the questionnaire, it was asked about the declared use of the smartphone in class in a habitual way, not specifically in the experiment. We found three major uses declared by the group of young participants in the experiment, $45 \%$ said they use the smartphone in class to chat when they are in class, followed in second place with $29 \%$ of cases, with the use from the smartphone in class to enter social networks. In third place with $5 \%$ the use of the smartphone was indicated to take photos, which usually corresponds to taking a snapshot of the blackboard or the presentation that can be projected in the classroom. A significant $21 \%$ said never use the smartphone in class, as can be seen in Figure 1. 
The questionnaire was interested in asking the participants about whether their teachers allowed them to use the smartphone in class. Faced with this question, do you have teachers who can use the smartphone in class? We find a result that indicates that most have a teacher who does not prohibit the use of the smartphone in class. $64 \%$ said so, while just over a third, specifically $36 \%$ said they had no teachers to allow the use of the smartphone in the classroom.

\section{¿Tienes profesores que permitan usar el móvil en clase?}

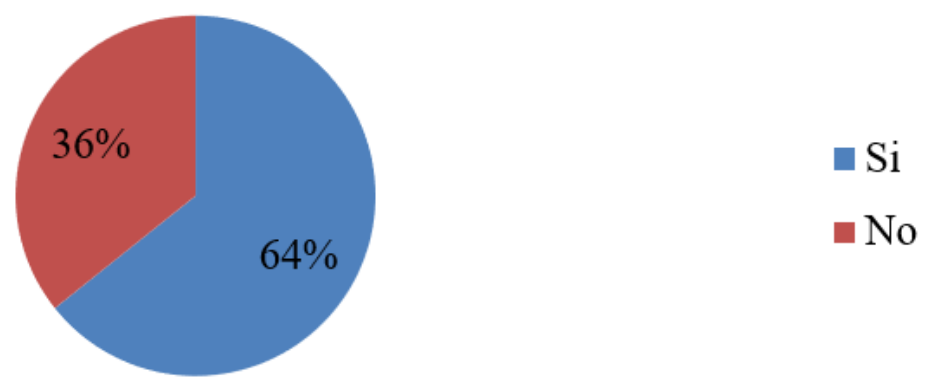

Figure 1. Use of the smartphone allowed or prohibited in class

Source: self made

He also asked if they considered that the smartphone is a fundamental element of distraction in class. $15 \%$ disagreed with this statement (9\% disagree and 6\% strongly disagree) while $46 \%$ agreed with it (14\% strongly agree and $32 \%$ agree). $39 \%$ did not show neither in disagreement nor according to that in class the smartphone is fundamentally an element of distraction.

\section{$¿$ Crees que el uso del smartphone en clase es fundamentalmente un elemento de distracción?}

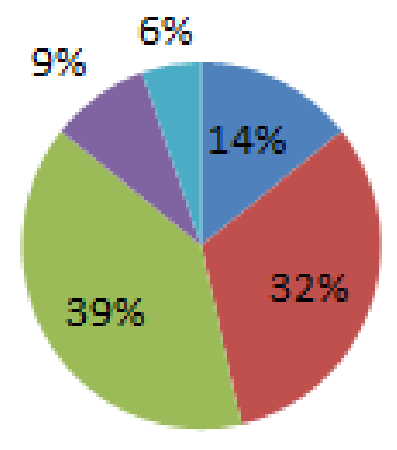

Totalmente de acuerdo

De acuerdo

Neutro

En desacuerdo

Totalmente en

de sacue rdo

Figure 2. Consideration of the Smartphone as a distraction element in the classroom

Source: self made

Asked if they considered that the smartphone could be a pedagogical tool in class, the majority agreed with it. The percentage was much more prominent in this case with $70 \%$ of responses that agreed or totally agree with it (20\% strongly agree and $50 \%$ agree), while only $9 \%$ disagreed (7\% disagree and $2 \%$ strongly disagree), as can be seen in Figure 3. 


\section{¿Crees que el uso del smartphone en clase puede ser una herramienta pedagógica?}

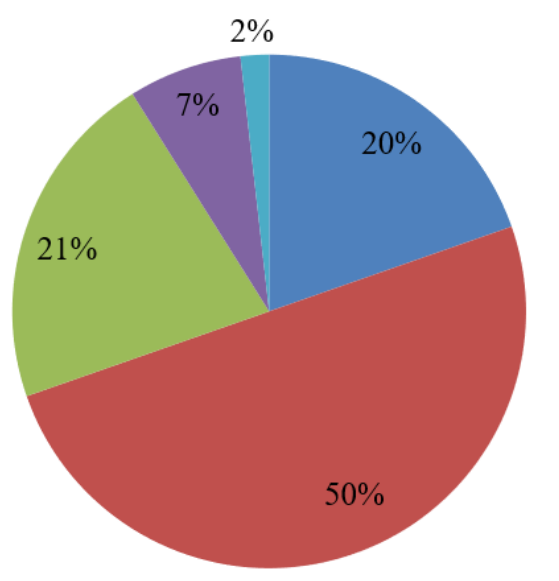

- Totalmente de acuerdo

- De acuerdo

Neutro

En desacuerdo

Totalmente en desacuerdo

Figure 3. Consideration of smartphone as a pedagogical tool in the classroom

Source: self made

\subsection{Results of the Neuroscientific Experiment}

Regarding the neuroscientific experiment, table 1 shows the different levels of attention (EDL) shown in the tests depending on the prohibition or not of the use of the smartphone. The difference in mean value is significant in both cases (Coef Sig. 0.000), although it is observed that there is a difference in the mean value in both groups, however it is not indicative of a large difference in the mean and standard deviation. Overall, the moments of duration of attention in the control group (S1) being slightly higher. This indicates that the spontaneous use of mobile does not significantly affect attention in class, so it would not be a disruptive element.

Regarding the kurtosis of table 1, the kurtosis of the control group indicates that the values of the distribution are more grouped around the average than those of the experimental group, which are less grouped around the mean. In the experimental group, the distribution is closer to the normal distribution, while in the control group it moves away.

In the case of the control group, the symmetry indicates that the distribution is tilted to the left, and in the case of the experimental group, the values are positioned to the right of the average values.

Table I. EDL statistics by session

\begin{tabular}{lll}
\hline & EDL (S1) Control group & EDL (S2) Experimental group \\
\hline Average & 199,5750 & 215,2604 \\
Typical deviation & 11,2575 & 11,3238 \\
Curtosis & 1,7110 & $-0,6694$ \\
Asymmetry & 1,1590 & $-0,1780$ \\
\hline
\end{tabular}

Source: self-made.

Table 2 shows the different levels of emotion (EDR) shown in the tests depending on the use of the smartphone. The difference in mean value is not statistically significant in any of the cases (Coef Sig. 0.174), while it is slightly higher in the experimental group (S1). This indicates that there are slightly more intense moments in the emotion.

In the case of Table 2, in the control group, the data are more dispersed around the mean, that is to say that it is much more pointed, it moves further away from the normal distribution than in the experimental group, which also presents values Away to the average but in smaller proportion.

In the case of symmetry, the two distributions are tilted to the left, the distribution is more inclined in the control group. 
Table II. EDR statistics per session

\begin{tabular}{lll}
\hline & EDR (S1) Control group & EDR (S2) Experimental group \\
\hline Average & 0,19037124 & 0,20931481 \\
Typical deviation & 0,21094639 & 0,21192068 \\
Curtosis & 24,540061 & 14,9245473 \\
Asymmetry & 3,86291206 & 2,86615836 \\
\hline
\end{tabular}

Source: self-made

Although it was not possible to establish a significant relationship between EDL and EDR (neither in general nor in the sessions considered individually), it should be noted that during the session in which the use of smartphone (S1) was prohibited, one of the two moments of emotional increase occurs in a situation of increased attention. In the other session this situation was not noticed.

\subsection{Uses of the Smartphone in the Classroom during the Experiment}

After the statements about their usual uses of the smartphone in the classroom and their considerations of the same, they were asked about the concrete use they had made in the classroom during the experiment. Logically this question was asked to the members of the group in which the use of the smartphone was not prohibited (S2). Of them, the majority declared using it to perform actions of instant communication via chat, fundamentally WhatsApp. 38\% reported having made this use during class.

Then there were two activities with the same percentage of use of $13 \%$, surfing the Internet looking for some type of information and look at the smartphone to check the time. Fourth, a percentage of $11 \%$ of the interviewees indicated that, without having been forbidden, they freely decided not to use the smartphone during the session. With smaller percentages other uses of the smartphone appear, such as entering social networks (9\%), checking email (6\%), uploading music (3\%) or using the smartphone's notes $(3 \%)$.

\section{¿Durante la clase ¿Qué uso has hecho del móvil?}

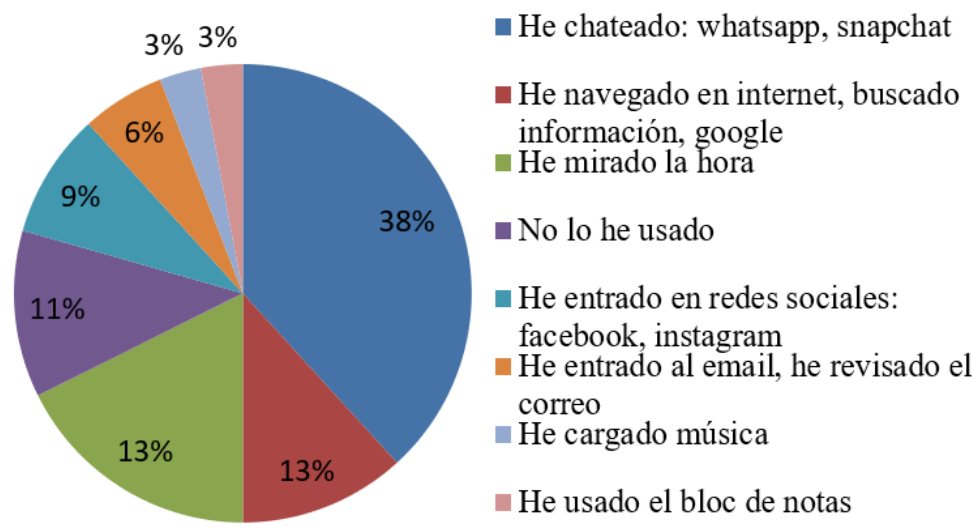

Figure 4. Typology of the use of the smartphone during the experiment class (S2)

Source: self made

\section{Conclusions and Discussion}

Students report having similar smartphone usage patterns, both in the classroom and outside the classroom. In this sense, most of the participants in our experiment pointed out that smartphones served them for educational purposes $(70 \%)$. If we want to address a possible integrative use of the smartphone in the classroom as a tool for communication and pedagogical interaction, it seems necessary not to ignore the use they declare to make of it. The students themselves recognize its pedagogical usefulness but are also aware at the same time that smartphones can be elements of distraction. Undoubtedly, many possibilities are still being wasted in this area, as indicated by the works of relation between theories of learning and the use of the smartphone of Brazuelo and Gallego (2011, 2014). 
These results coincide with most of the previous descriptive investigations on use in class and many other educational experiences in Spain, Repiso (2012) or Roig-Vila (2016), and other countries such as the experimental study of Moeller (2012) in five continents, using a qualitative comparative methodology or so many others about the use of WhatsApp in the classroom. Unlike these investigations, ours provides empirical evidence based on neuroscientific data on the influence of attentional and emotional elements.

The results of the neuroscientific experiment point out that there are no significant differences in the duration and average intensity of attention and emotion between the experimental group and the control group, during a university class with a combined didactic methodology of master class with support in audio-visual media and with or without a mobile phone, although the distribution of attention and emotion present slightly different results in both and more favorable to the control group.

It is understood that since there are no differences in means between the control group and the experimental group, the use of the smartphone should not be associated with disruption in a class of this nature, although the design of the experiment does not contemplate the individual disruption of the subjects, but the group's global behaviour.

When students are allowed to use the smartphone spontaneously in the classroom, students use it mainly to chat. Now, they also use it to look for information or take notes. This research corroborates, therefore, data from previous research that also concludes that students use mobile digital media generally for specific purposes such as chatting, searching for information and downloading materials.

Hypothesis 1 is confirmed, since the declared use of the smartphone in the classroom by millennials is the same as they usually do outside of it. So it corroborates what other authors say that the smartphone is inside the classroom regardless of its prohibition or encouragement.

Hypothesis 2 is confirmed, since the majority use of millennials in the smartphone in the classroom is chatting, facilitating instant communication, which would favor the participation of students through written messages if the use of smartphone were integrated into a didactic design. These results coincide with those that we have just pointed out in other global investigations that affirm that students use mobile phones fundamentally for chatting.

The hypothesis 3 is not confirmed that indicates that the spontaneous use of the smartphone in the classroom can distract the students in class because, although the declared perception of $47 \%$ of the students surveyed before the experiment consider that it is a disruptive element; however, the attention and emotion averages differences obtained by the electrodermal activity in the experiment do not indicate notable differences, although slightly favorable to the control group in attention and emotion.

These results help to understand, for example, the change of criteria in some countries such as Argentina, where the resolution banning cell phones for pedagogical use was repealed ten years after its use initially was banned in 2006, when Resolution No. 1728 was approved. That prohibited the use of mobile phones in the classrooms of public schools in the province of Buenos Aires, because "it decentrates and deconcentrates the teaching-learning process". Since 2016, the new official initiative is called "Bring your own device to the classroom", but they call into question decisions in the opposite direction such as those carried out in France since 2018 to prohibit smartphones in class.

In most of the western countries, which lack specific laws that regulate the use of mobile phones in schools, the debate on how to avoid their harm is opened, when it would surely be more convenient to delve into its possible didactic uses, given that after all, it can be an educational tool by allowing access to information on the Internet from the device they use most in their daily lives.

The results of our experiment showed no significant differences in attention. The fact that the results of this research should be considered exploratory, does not detract from their value. Future complementary studies should delve into the content of the most appropriate teaching methodologies or the due use of complementary technologies that help to study this issue in greater depth. In any case, the prohibition of their use of smartphones in classrooms due to the possible interruption of pedagogical work must be scientifically based at all times.

\section{References}

Aiger, M., Palacín, M., \& Cornejo, J. M. (2013). La señal electrodérmica mediante Sociograph: metodología para medir la actividad grupal. Revista Internacional de Psicología Social: International Journal of Social Psichology, 28(3), 333-347. https://doi.org/10.1174/021347413807719102

AIMC. (2019). Estudio Navegantes en la red. Retrieved from https://www.aimc.es/otros-estudiostrabajos/navegantes-la-red/infografia-resumen-21o-navegantes-la-red/

Alonso Ferreiro, A. y Fraga Verela, F. (2016). La dimensión comunicativa de la competencia digital en la 
generación Abalar (Escuela 2.0). En: Rosabel Roig-Vila (Ed.), EDUcación y TECnología. Propuestas desde la investigación y la innovación educativa. Octaedro: Barcelona.

Anohah, E., Oyelere, S. S., \& Suhonen, J. (2017). Trends of mobile learning in Computing Education from 2006 to 2014: A systematic review of research publications. International Journal of Mobile and Blended Learning (IJMBL), 9(1), 16-33.

Artopoulos, A. Y Sansone M. (2016). Caso: Celulares en el Colegio Carmen Arriola de Marín. En: Coords. Alejandro Artopoulos y Carina Lion, La escuela de las pantallas. Referentes y casos para la transición pp. 207-218. Ariel: Madrid

Belk, R. W. (2013). Extended self in a digital world. Journal of Consumer Research, 40(3), 477-500. https://doi.org/10.1086/671052

Botías Cegarra, R. F. (2016). El smartphone en sexto de primaria: estudio de caso y propuesta para su inserción en el aula. En: Rosabel Roig-Vila (Ed.), EDUcación y TECnología. Propuestas desde la investigación y la innovación educativa. Octaedro: Barcelona.

Brazuelo, F., \& Gallego, D. (2011). Mobile Learning. Los dispositivos móviles como recurso educativo. Sevilla: MAD Eduforma.

Brazuelo, F., \& Gallego, D. (2014). Estado del Mobile Learning en España. Educar em Revista, Curitiba, Brasil, Edição Especial n. 4/2014, p. 99-128. Editora UFPR

Cavanaugh, J. M., Giapponi, C. C., \& Golden, T. D. (2016). Digital technology and student cognitive development: The neuroscience of the university classroom. Journal of Management Education, 40(4), 374-397. https://doi.org/10.1177/1052562915614051

Cetinkaya, L. (2017). The Impact of Whatsapp Use on Success in Education Process. The International Review of Research in Open and Distributed Learning, 18(7). https://doi.org/10.19173/irrodl.v18i7.3279

Dorsey. J (2016) Landmark Study Series on the Generation after Millennials. Retrieved from http://jasondorsey.wpengine.com/igen-gen-z/ason Do2016

Estefanía, J. (2017). Abuelo, ¿cómo habéis consentido esto? Barcelona: Planeta.

Esteve, J. M. (2016). Uso complementario de TIC en el análisis de imágenes y de los comentarios de texto científicos en cursos tempranos de la enseñanza universitaria. En: Rosabel Roig-Vila (Ed.), EDUcación y TECnología. Propuestas desde la investigación y la innovación educativa. Octaedro: Barcelona.

García Vega, M. A. (2016). Los 'millennials' y los 'centennials', dos generaciones que valen 19 billones. El País. Retrieved October 23, 2016 from http://economia.elpais.com/economia/2016/10/20/actualidad/ 1476985002_101940.html

Guerrero, C., Jaume, A., Juiz, C., \& Lera, I. (2016). Use of Mobile Devices in the Classroom to Increase Motivation and Participation of Engineering University Students. IEEE Latin America Transactions, 14(1), 411-416. https://doi.org/10.1108/10650741111117815

Hershkovitz, A., Abu Elhija, M., \& Zedan, D. (2019). WhatsApp is the message: Out-of-class communication, student-teacher relationship, and classroom environment. Journal of Information Technology Education: Research, 18, 63-95. https://doi.org/10.28945/4183

Kotilainen, S. \& Sol-Britt, A. G. (2010). Media Literacy Education: Nordic Perspective. Göteborg: Nordicom: University of Gotenburg.

Martínez Herrador, J. L., Monge Benito, S., \& Valdunquillo Carlón, M. I. (2012). Medición de las respuestas psicofisiológicas grupales para apoyar el análisis de discursos políticos. Tripodos, 29, 53-72.

Mazana M. Y. (2018). Social media in the classroom: whatsapp a new communication tool for enhanced class interactions. Business Education Journal, II(I).

Menchaca, I., Guenaga, M., \& Romero, S. (2015). Mobile devices, powerful teaching tools in the engineering classroom, Global Engineering Education Conference (EDUCON), 2015 IEEE, pp. 577-581, 18-20 March 2015. https://doi.org/10.1109/EDUCON.2015.7096027

Molina, A.I., Navarro, O., Lacruz, M. y Ortega, M. (2017). El empleo de técnicas de seguimiento ocular para evaluar materiales educativos en Educación Primaria. Revista de Educación, n ${ }^{\circ} 376$ abril-junio 2017, pp.85105. https://doi.org/10.4438/1988-592X-RE-2017-376-345

Navaridas, F., Santiago, R., \& Tourón, J. (2013). Valoraciones del profesorado del área de Fresno (California 
Central) sobre la influencia de la tecnología móvil en el aprendizaje de sus estudiantes. Relieve, 19(2).

Pérez-Tornero, J. M. y Tayie, S. (2012). La formación de profesores en educación en medios: currículo y experiencias internacional. Comunicar, Revista Científica Iberoamericana de Comunicación y Educación, $\mathrm{n}^{\mathrm{o}}$ 39; vol. XX; época II $1^{\circ}$ semestre. pp.11-14. https://doi.org/10.3916/C39-2012-02-05

Prensky, M. (2001). Digital natives, digital immigrants part 1. On the Horizon, 9(5), 1-6.

Repiso, R. (2012). El uso de smartphones con fines pedagógicos, una experiencia desde Finlandia. Retrieved from https://revistacomunicar.files.wordpress.com/2012/07/7293987664_0ed56e5676_c.jpg

Tapia, A. y Martín, E. (2016). Neurociencia aplicada a la televisión: Medición de la atención y la emoción de la serie "Forever". Revista de Comunicación Vivat Academia. Marzo 2016, Año XIX, No 134. pp 69-82. https://doi.org/10.15178/va.2016.134.69-82

Tayie,S., Pathak-Shelat, M. e Hirsjarvi, I. (2012). La interacción de los jóvenes con los medios en Egipto, India, Finlandia, Argentina y Kenia. Comunicar, Revista Científica Iberoamericana de Comunicación y Educación, $\mathrm{n}^{\circ}$ 39; vol. XX; época II $1^{\circ}$ semestre. pp. 53-63. https://doi.org/10.3916/C39-2012-02-05

Tela Provincia de Buenos Aires (27/10/2016). Derogan la resolución que prohibía los celulares para uso pedagógico. Retrieved from http://www.telam.com.ar/notas/201610/168572-celulares-uso-pedagogicoescuelas-bonaerenses.html

The Center for Generational Kinetics and Jason Dorsey (2016). The Center for Generational Kinetics, LLC. Retrieved from http://genhq.com/wp-content/uploads/2016/01/iGen-Gen-Z-Tech-Disruption-ResearchWhite-Paper-c-2016-Center-for-Generational-Kinetics.pdf

Urena, C. (2017). Cómo conectar con la Generación Z. AdReaction: conectando generaciones de Kantar Millward Brown. Retrieved from http://es.kantar.com/empresas/marcas/2017/enero-2017-c\%C3\%B3mo-conectar-conla-generaci\%C3\%B3n-z/

Ureta S., Artopoulos, A., Muñoz, W. y Jorquera, P. (2011). Cultura juvenil smartphone en un entorno urbano: Un estudio de caso en Santiago de Chile. En: Castells, M., Hernán Galperin y Mireia Fernández-Ardevol (2011), Comunicación smartphone y desarrollo económico y social en América Latina. Madrid: Ariel.

Yaacov J. Katz, \& Yaacov B. Yablon, (2011). Affect and digital learning at the university level. Campus-Wide Information Systems, 28(2), 114-123. Retrieved from https://doi.org/10.1108/10650741111117815

\section{Copyrights}

Copyright for this article is retained by the author(s), with first publication rights granted to the journal.

This is an open-access article distributed under the terms and conditions of the Creative Commons Attribution license (http://creativecommons.org/licenses/by/4.0/). 